\title{
THE RELIEF OF POVERTY, ATTITUDES TO LABOUR, AND ECONOMIC CHANGE IN ENGLAND, I660-1782*
}

During the past two or three decades economic and social historians have displayed a sustained interest in the pre-conditions of the Industrial Revolution in England, and among the many explanations of this remarkable break-through into modern industrialization the role of labour (including population) has been accorded a prominent place. Yet although questions about wages, labour supply, productivity, poverty, and poor relief have been staple ingredients in the economic and social historian's diet ever since his discipline began to take shape in the late nineteenth century, there are still serious gaps in our knowledge of the size, composition, quality and living standards of the English labour force in the late seventeenth and eighteenth centuries. Some of these gaps may eventually be filled, at least partially, by detailed empirical studies of local and regional demographic, economic and social conditions. But even the most sanguine researcher must admit that there will continue to be deficiencies of data and unanswerable questions, so the need for interpretative, even speculative, studies will remain. The present paper falls within this latter category, for it is mainly concerned with the relationships between ideas, policies and conditions affecting the English labouring poor in the period under examination. It combines a review of the present state of knowledge of these matters with some speculative observations about causal connections and the possibilities of future research.

A cursory glance at the voluminous literature dealing with the English poor in the late seventeenth and eighteenth centuries reveals such a bewildering variety of attitudes, practices and conditions that

* This article was originally prepared for the Sixth Meeting of the International Institute of Economic History "Francesco Datini" at Prato in April 1974. 
it is legitimate to wonder whether any discernible patterns can be traced. Traditional attitudes towards poverty were disintegrating under the combined influence of the decline of religion and the spread of scientific ideas; the so-called rise of economic individualism meant, in social affairs, a decline of paternalistic central-government interference and a growth of parochial responsibility, with the inevitable result that general legislative enactments afford an even less reliable guide to local administrative realities than in the Tudor and Stuart periods; and although recent historians agree that this was a time of substantial economic advance, they also recognise that this process was very unevenly distributed, both in space and time. Consequently, although scholars have not hesitated to impose their subjective patterns on the available evidence, it is clear that any large-scale or long-term generalisations must be cautiously expressed and interpreted if they are not to do violence to the facts.

The plan of the paper is as follows. Section II outlines the general economic and social trends of the period, with special reference to prices and demographic changes. Section. III describes some characteristic features of the economic literature of the time and certain broad trends in poor-law ideas and practices. Section IV examines the relationship between public relief expenditures and private charity, and offers some suggestions about their combined effects, while the final section, $V$, reviews the argument and raises certain questions about future research prospects.

\section{II}

Recent studies of general trends in the English economy between 1660 and $\mathbf{1 7 8 0}$ have stressed the multiplicity of factors at work and the extreme difficulty of disentangling them and specifying their interconnections. Yet, despite the acknowledged importance of natural advantages, political stability, social fluidity, and the growth of trade, manufacturing, technology, etc., attention has lately been focussed on agricultural prices and population changes - matters of direct interest to all students of labour and poverty. The period as a whole was one of substantial, if uneven, economic expansion affecting in differing degrees all sectors and regions, and despite serious shortcomings in the available evidence there is a broad consensus of opinion about the main features. In demographic terms there was a substantial growth of population from the mid-seventeenth century, probably with a marked acceleration around the 1680's and 1690's, a deceleration thereafter to about 1720 followed by stagnation until about 1745 , and then a renewed upsurge which continued throughout the Industrial 
Revolution. ${ }^{1}$ During the century from 1650 agricultural prices remained comparatively low, with wheat prices taking a "decided downward plunge" until the third quarter of the eighteenth century, when "the steep rise of population was followed by a still steeper rise of prices". As a result there was a general upward trend in the purchasing power of the mass of the people, so that from the later 1740's "a foundation for mass consumption was being laid by the inverse developments of population and progressive agriculture". ${ }^{2}$

Owing to the lack of reliable statistical data there is, unfortunately, no parallel consensus of opinion as to the level, rate of growth, and fluctuations of the national income, or its distribution among various sectors, regions or groups. There has been widespread acceptance of Professor Coleman's judgment that the initial level of living standards was low, and that contemporary observers were correct in attaching great importance to increases in the quantity and improvements in the quality of the labour force, since there was comparatively limited scope for new techniques or heavy capital investment in manufacturing processes. ${ }^{3}$ But while many late-seventeenth- and eighteenth-century observers considered that the English "poor" enjoyed higher money and real wages than their Scottish, Irish and continental European counterparts, ${ }^{4}$ there were considerable divergences of opinion as to the desirability of this state of affairs.

In addition to these general trends there were also frequent shortterm changes and significant regional variations in economic and social conditions, though they rarely fall into neat geographical or chronological patterns. Periodic crises impinged directly, and often

1 Although there are significant disagreements among the experts on matters of emphasis and detail, this account is based on the work of one leading authority: J. D. Chambers, Population, Economy, and Society in Pre-Industrial England, ed. by W. A. Armstrong (Oxford, 1972), esp. pp. 22-24.

${ }^{2}$ Ibid. No attempt will be made here to outline major developments in commerce, agriculture, manufacturing or technology, for such an account would take us too far afield. For reliable general textbooks see Charles Wilson, England's Apprenticeship 1603-1763 (London, 1965), and L. A. Clarkson, The Pre-Industrial Economy in England 1500-1750 (London, 1971).

${ }^{3}$ D. C. Coleman, "Labour in the English economy of the seventeenth century", in: Economic History Review, Second Series, VIII (1955-56), esp. pp. 283-84. This view has been generally accepted by subsequent historians.

4 This opinion can be traced back well beyond our period. Cf. Professor F. J. Fisher's delightful quotation from a sixteenth-century pamphlet: "Oh if thou knewest thou Englishe man in what welth thou livest and in how plentifull a Countrye: Thou wouldst vii times of the day fall flat on thy face before God, and geve him thanks, that thou wart born an English man, and not a french pezant, nor an Italyan, nor Almane." Cited in Essays in the Economic and Social History of Tudor and Stuart England, ed. by F. J. Fisher (Cambridge, 1961), p. 13. 
severely, on the poorest members of the community, many of whom had no cushion of savings or alternative sources of income in times of distress. Although the progress of agriculture was tending to reduce the severity of bad harvests, which seem to have occurred less frequently between 1650 and 1750 than in earlier periods, there were many other disruptions of economic life attributable to adverse weather, epidemics (which were of diminishing severity in the eighteenth century), ${ }^{1}$ commercial crises and wars. And as we shall see, public and private relief may have had a significant effect in reducing the impact of these misfortunes, especially for the poorest members of society.

At this point, however, we must define our terms more carefully more carefully, that is, than contemporary commentators, most of whom failed to identify precisely or consistently the social and occupational groups to which they were referring. At the end of the period Arthur Young doubtless exaggerated in saying that "the labouring poor is a term that none but the most superficial reasoners can use; it is a term that means nothing"; 2 yet we must heed the late Professor T. S. Ashton's warning that

"No generalisations are more unsafe than those relating to social classes. The wide diversity of organisation in English agriculture and manufacture was matched by similar diversity in the conditions and attitudes of the workers. Many of the writers of treatises and pamphlets tended to ignore these differences; they were obsessed with the problem of the paupers; and, since in an age of economic fluctuations independent workers were liable to fall into poverty, there was a tendency to identify them with that sub-stratum of the population which was rarely, if ever employed."3

For the purposes of identifying the poor, the most valuable statistical benchmarks are those provided by Gregory King in the 1680's and 1690 's, who classified $23 \%$ of the population as "labouring people and out servants" and an additional $24 \%$ as "cottagers and paupers", maintaining that the annual family expenditures of both groups normally exceeded their incomes. ${ }^{4}$ Twentieth-century historians would not perhaps paint quite so bleak a picture - it has, for example,

1 This is one of the major themes of Professor Chambers's posthumous work referred to above, p. 100, note 1 . For a general study of short-term changes see T. S. Ashton, Economic Fluctuations in England 1700-1800 (Oxford, 1959).

2 Northern Tour (1768), IV, p. 467.

3 An Economic History of England: The Eighteenth Century (London, 1955), p. 201.

${ }^{4}$ Coleman, loc. cit., pp. 283-84. 
recently been suggested that about $20 \%$ of the late-seventeenthcentury population were actually paupers in receipt of public or private charity, but that up to a further $30 \%$ were at risk of becoming paupers at any given time. ${ }^{1}$ It is virtually impossible to identify the hard core of those actually destitute for any length of time, but it is essential to distinguish between the impotent poor - such as widows, orphans, the aged, infirm, lunatics, vagrants and criminals - and the larger category of the industrious poor - mainly unskilled, low-paid labourers, weavers, manufacturers, seamen, miners, porters, etc., who were always vulnerable to any significant loss of earnings or rise in living costs. As is well known, contemporary observers usually took it for granted that the impotent poor should be supported, and that vagrants and criminals should be suitably punished, for these were straightforward Christian social duties. But they were much more concerned at the supposedly ever-growing numbers of dependent industrious poor, those able-bodied workers who were either unwilling to work or unable to find suitable or sufficient employment, whether permanent or temporary.

Any attempt to calculate the number of persons in the various categories of the poor must necessarily be treated with extreme caution owing to the lack of reliable data. Nevertheless, a rough indication of the relative magnitudes involved can be obtained by comparing two available "guesstimates" - one, by Professor Coleman, based on a Lichfield enumeration of 1695, the other by $\mathrm{Dr} J . \mathrm{D}$. Marshall, based on official returns in the early nineteenth century. ${ }^{2}$ In the Lichfield case it appears that $16.8 \%$ of the town's population was pauperized, and of this total children under 15 comprised $47.3 \%$, and those aged 60 and over a further $17 \%$. According to Dr Marshall, children under 15 constituted approximately $50 \%$ of permanent outrelief cases in the Speenhamland counties in 1802-03, while the aged, sick or infirm comprised somewhere between $9 \%$ and $20 \%$ of the total. The two sets of figures are, of course, strictly speaking non-comparable - for instance, Dr Marshall's figures exclude indoor relief cases, and both may be subject to considerable margins of error. Nevertheless, it seems reasonable to accept Dr Marshall's estimate that able-bodied adult male labourers probably constituted less than $20 \%$ of the pauper total (about $2 \%$ of the entire population) ${ }^{3}$ as broadly true of 1 Cf. Wilson, op. cit., p. 231 ; Clarkson, op. cit., p. 233.

2 Coleman, loc. cit., pp. 285-86; J. D. Marshall, The Old Poor Law 1795-1834 (London, 1968), esp. pp. 33-35.

3 Of course this proportion varied widely from time to time and place to place, according to local employment opportunities. As Dr Marshall suggests, careful local studies could undoubtedly provide a much more detailed and accurate picture of these variations than is currently available. 
the whole period. Yet this was the category that attracted by far the greatest attention from contemporary observers. In the next section we shall consider why this was so.

\section{III}

Before reviewing contemporary attitudes to the labouring poor it is appropriate to recall some general features of late-seventeenth- and eighteenth-century economic literature. Although economics as a discipline was still in a pre-professional stage, for there was as yet no readily identifiable group of specialist economic writers, there was a discernible long-term development of an autonomous body of general principles of the "science of trade", culminating in the great mideighteenth-century systematic works by Richard Cantillon, David Hume, Sir James Steuart and Adam Smith. ${ }^{1}$ The emergence of an autonomous body of economic ideas was accompanied by a diminished emphasis on ethical and religious considerations, which reflected the declining role of theology and the increasing influence of the natural sciences in intellectual life. These tendencies were, of course, much more apparent in the analysis of prices, monetary problems and trade than in discussions of poverty and employment, for most contemporary authors were incapable of suppressing their latent anthropocentrism and treating labour purely as a factor of production, divorced from all humanistic considerations. There was, it is true, an increasing prevalence of a "commercial spirit" in the general literature of the time, a change which reflected the combined influence of economic progress and contemporary writers' responsiveness to the growth of a substantial new middle-class readership. ${ }^{2}$ Nevertheless, traditional Christian doctrine, unadulterated sentiment and class prejudice, continued to colour attitudes to poverty and the poor law, especially in so far as this was viewed as a matter of public or private charity.

1 This is a major theme of innumerable histories of economic thought. Of special interest in the present connection is W. Letwin, The Origins of Scientific Economics, English Economic Thought 1660-1776 (London, 1963).

2 Historians of literature seem much more aware of the significance of this point than historians of economics. See, for example, Ian Watt, The Rise of the Novel, Studies in Defoe, Richardson and Fielding (London, 1960); J. W. Saunders, The Profession of English Letters (London, 1964); and other studies of the output of seventeenth- and eighteenth-century novels, periodicals and newspapers. As there was then no distinct category of "economists" or economic writers, it is necessary to view economic writings in relation to other categories of literature. This point is especially important in considering labour and poverty in view of the difficulty of distinguishing economic treatises from poorlaw pamphlets and the vast volume of religious tracts and ethical homilies. 
Indeed, those eighteenth-century authors who were constantly discussing the relationship between reason and the passions would doubtless have understood and appreciated the current sociological distinctions between the comparative rationality of exchange relationships in the market place and the more emotional, affective considerations of recognition and deference entailed in gift-giving. ${ }^{1}$ Yet there is no way of avoiding the complexities of the problem, for the question of poverty was a unifying theme linking debates about the level of economic activity, the balance of trade, prices, wages, employment, the poor law, workhouses and charity schools. The historian of economic thought and policy, as distinct from the historian of economic analysis, cannot confine himself to the embryonic treatises on systematic economics: he must go beyond the many pamphlets directly focussed on poor-law practice and at least sample the innumerable sermons, speeches and commentaries in the growing periodical literature of the time. Needless to say, the following summary statements will not attempt to encompass so ambitious a scope.

Despite the enormously varied and often conflicting views expressed by late-seventeenth- and eighteenth-century writers on economic and social questions, there was virtual unanimity on one central point the great importance attached to a large, well-ordered, healthy and industrious population. This consensus cannot be explained simply in economic terms - political, social and military considerations were also recognized. But the economic aspect was paramount. The coexistence of concern about poverty and the desire for a large population was not paradoxical, for the need to discourage idleness and prevent unemployment was generally acknowledged, and, despite all the evidence to the contrary, there remained a remarkably optimistic conviction that these difficulties could be overcome. Indeed, so great was the emphasis on the importance of employment that it came to dominate the discussion of all aspects of economic activity, including the money supply, the level of prices, the size and composition of output, and the balance of international accounts. ${ }^{2}$ With the passage

1 See, for example, Neil Smelser, "A Comparative View of Exchange Systems", in: Economic Development and Cultural Change, VII (1959), pp. 173-82, and Alvin Gouldner, "The Norm of Reciprocity", in: American Sociological Review, XXV (1960), pp. 161-78.

2 It is noteworthy that, despite the prevalent belief that "the majority must be kept in poverty that the whole might be rich", there was no serious discus ion of the distribution of income or wealth. Cf. the classic study by Edgar S. Furniss, The Position of the Laborer in a System of Nationalism, A Study of Labor Theories of the Later English Mercantilists (New York, 1957; originally published in 1920). The quotation is from p. 8. 
of time there was an increasing emphasis on the role of money as a medium of exchange, a positive stimulus to economic activity rather than a passive store of value; prices were considered to be too low if producers were impoverished or unemployed, and too high if our competitive power was thereby undermined; commodities produced by labour-intensive methods were preferred to those which employed few hands; and while exports were esteemed more highly than goods destined for the home market, this was not merely because they yielded foreign currency or bullion, but also because they represented an "export of work" and therefore constituted "foreign-paid incomes". 1

Although this body of ideas never acquired the systematic qualities that would justify us in describing it as economic theory, in the full present-day sense of that term, it was by no means lacking in coherence. On the contrary, the growing awareness of the interrelationships between the quatity of money, the balance of trade and the level of employment displayed by the leading economic writers of the period has persuaded some over-enthusiastic modern commentators to regard it as an embryonic form of Keynesian economics. ${ }^{2}$ This framework of ideas formed the intellectual background to the more economically sophisticated accounts of the nature and effects of the poor law; and in certain cases the role of private charity was also taken into the reckoning. ${ }^{3}$

As the late seventeenth and early eighteenth centuries were the age of political arithmetic, it was inevitable that some authors would attempt to calculate the losses to the nation resulting from the failure to utilise the labour force fully and effectively, whether this was due to a shortage of money, voluntary idleness, the number of holidays, or

1 Cf. E. A. J. Johnson, The Predecessors of Adam Smith, The Growth of British Economic Thought (London, 1937), ch. XV. According to Furniss, op. cit., p. 41, "In Mercantilistic thought, as in all systems of nationalism, a nationally valuable was distinguished from a nationally useless population by the test of employment, and this test comprised not only considerations of the amount but also of the kind of occupation."

2 This view was, of course, propagated by J. M. Keynes himself, in the final chapter of his General Theory of Employment Interest and Money (London, 1936). One of the principal missing links in the eighteenth-century view was the failure to integrate the rate of interest and the marginal efficiency of capital into the system, largely because of a lack of understanding of the process of investment.

${ }^{3}$ For example, by Sir James Steuart: "provided man be made to labour, and make the earth produce abundantly, and provided that either authority, industry, or charity, can make the produce circulate for the nourishment of the free hands, the principle of a great population is brought to a full activity." An Inquiry into the Principles of Political Oeconomy, ed. by Andrew S. Skinner (Edinburgh, 1966; originally published in 1767), I, p. 67. See also p. 94. 
even the labourer's failure to reproduce his species. ${ }^{1}$ But unfortunately these endeavours cannot be taken very seriously; nor can we uncritically accept the method of attaining representative opinions suggested by John Collins, who believed it possible to weigh up the views in the literature on trade so as to obtain a "balance of doctrines". 2 No scholar has yet been bold enough to review the voluminous and highly miscellaneous body of opinions about the problems of employment, poverty and poor-law policy in an effort to identify and assess general trends of thought which could be related, with due allowance for time lags, to changes in contemporary economic and social conditions. The available secondary literature on economic ideas and policy is quite inadequate for this purpose; yet without such an undertaking there inevitably appears to be a lack of connection other than accidental or occasional - between contemporary attitudes and practice. It is therefore necessary, while acknowledging the risks involved, ${ }^{3}$ to offer some provisional generalisations about changes in contemporary attitudes to the poor before attempting to account for these changes in terms of the evolution of ideas and/or changes in contemporary economic and social conditions.

According to the leading poor-law historians, ${ }^{4}$ attitudes to the poor between 1660 and 1780 fall into three broad phases. From the Restoration until some time around the turn of the century, genuine concern for their welfare was coupled with an increased emphasis on the need to provide employment for the able-bodied - whether in workhouses, for those willing to work, or in Houses of Correction or other quasipenal institutions, for the vagrant, recalcitrant or congenitally idle. In this phase there was genuine enthusiasm for workhouse schemes, derived largely from the over-optimistic assumption that in properly regulated conditions it would be possible to make a profit by selling

1 Cf., for example, David Bindon, A Scbeme for Supplying Industrious Men with Money to Carry on their Trades, 3rd ed. (Dublin, 1750; originally published in 1729), p. 62; Sir Joshua Gee, The Trade and Navigation of Great Britain, 4th ed. (London, 1738; originally published in 1729), p. 134; Lawrence Braddon, An Abstract of the Draught of a Bill for Relieving, Reforming and Employing the Poor (London, 1717), p. viii; and John Bellers, An Essay toward the Improvement of Physick [...] with an Essay for Imploying the Able Poor (London, 1714), p. 111, who estimated the loss of every industrious labourer capable of having children as equivalent to a "Two Hundred Pound Loss to the Kingdom". ${ }^{2}$ As quoted by Letwin, op. cit., pp. 112-13.

${ }^{3}$ In particular, the risks of obscuring the variety of opinions and the variations in local economic and social conditions and poor-law practices.

4 Dorothy Marshall, The English Poor in the Eighteenth Century, A Study in Social and Administrative History (London, 1926), and Sidney and Beatrice Webb, English Poor Law History, Part I: The Old Poor Law [English Local Government, Vol. 7] (London, 1927). 
the products of pauper labour. Although this expectation was waning soon after 1700 , in face of accumulating evidence of past failures, workhouse schemes continued to be advocated and initiated throughout the eighteenth century by those who hoped either to defray part of the cost of maintaining the poor or to effect some reformation of their idle habits. ${ }^{1}$

From the beginning of the new century, however, there was a second phase, when a strident note of hostility became more widespread, and the workhouse was increasingly viewed as a device for deterring those who could find work but preferred to live off parochial relief or private charity. ${ }^{2}$ The so-called Workhouse Test Act of 1723, which permitted parishes to form unions to construct workhouses for this purpose, was a by-product of this new approach, and, like other poor-law statutes in the period, it was based directly on previous local experiments. Another feature of this second phase was the widespread support given to the practice of "farming" either the whole poor or some special category of paupers, in the belief that this was the easiest and least expensive method of discharging a persistent and burdensome parochial responsibility. Farming involved the application of commercial methods to the poverty problem, and it usually had disastrous consequences for the poor themselves - so much so, that from the mid century there was a growing revulsion at the foul and degrading conditions to which the indoor poor were subjected, and an outcry not only against farming, and workhouses in general, but also sometimes against the entire poor-law system. It is difficult to account for this second phase in attitudes to the poor. Disappointed expectations among those who had put their faith in workhouse schemes was surely one element, and concern at rising poor rates accompanied by food riots and other public disturbances in the $1690{ }^{\prime} \mathbf{s}^{3}$ may also have played a part. Daniel Defoe's pamphlet Giving Alms no Charity (1704) was probably influential; and it may

1 Just as it was widely held that the children of the poor must be "inured to early labour", so too it was argued, for adults, "better to burn a thousand men's labours for a time, then to let those thousand men by non-employment lose their faculty of labouring". William Petty, Economic Writings, ed. by C. H. Hull (Cambridge, Mass., 1899), p. 60.

2 This view, of course, depended on the assumption that employment opportunities were available for the unemployed poor, a view that gained increasing support towards the mid-century. It was compatible with a growing scepticism towards interventionist "make-work" schemes.

${ }^{3}$ Cf. Max Beloff, Public Order and Popular Disturbances, 1660-1714 (Oxford, 1938); R. B. Rose, "Eighteenth Century Price Riots and Public Policy in England", in: International Review of Social History, VI (1961), esp. pp. 279-81. 
have been instrumental in defeating Sir Humphrey Mackworth's Workhouse bill, as the Webbs suggest; ${ }^{1}$ but it is difficult to accept that it had a lasting impact. It seems possible that attitudes to labour became more hostile as food prices fell and real incomes rose, if the labourers responded by working less and taking more leisure time. Unfortunately this contention, too, though supported by innumerable complaints in the pamphlet literature, cannot be adequately substantiated in the present state of our knowledge. Comparisons with underdeveloped countries suggest that a negative response to the availability of higher real earnings would have been most likely in stagnant rural areas remote from expanding markets and available supplies of manufactured goods. However, further research is needed on this point, and at present we can only speculate that at a time when British exports were suffering from increased foreign competition in Europe, it appeared to many observers that opportunities for economic growth were being lost owing to an idle, unresponsive and overpaid labour force.

The third phase in attitudes towards the poor can be dated approximately from the mid-eighteenth century, and became more apparent with the rise of food prices in the late 1750's and 1760's. ${ }^{2}$ As in earlier periods, there was no uniformity of outlook: the poors' critics could still be heard as well as their defenders. ${ }^{3}$ But, on the whole, a more sympathetic attitude prevailed, and this was firmly based on a combination of moral philosophy and economic analysis, reinforced by growing public concern at the distress resulting from the rising prices of foodstuffs. It is surprising that public sympathy was so widespread

1 S. and B. Webb, op. cit., pp. 113-16. They remark that Defoe threw into the discussion "the hardest possible stone of economic disillusionment and worldly cynicism". A comparable mood was evident in Bernard Mandeville's Fable of the Bees (1714) and his Essay on Charity Schools (1723), both of which contain a detached, cynical and calculating attitude to the problem of poverty.

2 For a more detailed account of this phase see my two articles "Changing Attitudes to Labour in the Mid-Eighteenth Century", in: Economic History Review, Second Series, XI (1958), pp. 35-51 (reprinted in Essays in Social History, ed. by M. W. Flinn and T. C. Smout (Oxford, 1974)), and "Economic Thought and Poor Law Policy in the Eighteenth Century", ibid., XIII (1960) pp. 39-51.

3 In a later article Richard C. Wiles demonstrated that support for "high wages" was less infrequent in the pre-1750 period than $\Upsilon$ had supposed. Cf. "The Theory of Wages in Later English Mercantilism", in : Economic History Review, Second Series, Vol. XXI (1968), pp. 113-26. Nevertheless the main argument about the difference in attitudes between the two periods is unaffected, for this was not simply a matter of high wages. The discussion of wage levels (which was, in any case, more complex than Wiles suggested) was only part of a larger corpus of ideas and beliefs. It would, however, be inappropriate to pursue the matter further at this juncture. 
in view of the growing evidence of social unrest, which was often serious enough to alarm the authorities responsible for law and order. But from the standpoint of the poor themselves this appears to have been largely a defensive reaction designed to preserve the higher living standards which many had enjoyed during the previous period.

Although it is a proposition virtually impossible to demonstrate conclusively, there seems little reason to doubt that the improvement in living standards enjoyed by the "industrious poor" in the second quarter of the eighteenth century raised their conception of a decent or comfortable level of subsistence and generated rising expectations, which were frustrated when the cost of living increased in the post-1755 period. ${ }^{1}$ At the same time a significant number of informed observers paid tribute to the skill, industry and effort of British labourers, suggesting that a more positive response to incentives may have been forthcoming after the mid-century than in earlier periods, when complaints about idleness and absenteeism were prevalent. ${ }^{2}$ Indirect support for this general interpretation can be found in recent studies of popular disturbances, which show how frequently, and often how effectively, the lower orders ventilated their demands for a moderate subsistence in times of dearth. These outbreaks were not merely "rebellions of the belly", unthinking Pavlovian responses to immediate pressures; they reflected positive claims and aspirations stemming from an underlying conception of natural justice, a just price, or a traditional "moral economy of provision". ${ }^{3}$ While the crowd's action probably depended on the existence of a hard core of leaders prepared to challenge the forces of law and order, the supporting cast was recruited from among those who were marginally indigent and threatened with pauperization by the decline in their real income.

The frequency and varied character of these outbreaks cannot be fully described here. But it is worth noting that in the earlier part of our period, when bad harvests were less frequent, the governing classes

1 This is in accordance with the views expressed by Professor Chambers, who emphasized the relationship between population, economic expansion, and rising expectations. Op. cit., pp. 30, 145 .

2 Any detailed examination of this possibility would, of course, call for a careful distinction between different categories of the labouring poor, different occupations and different regions.

3 See, for example, Edward P. Thompson, "The Moral Economy of the English Crowd in the Eighteenth Century", in : Past \& Present, No 50 (1971), pp. 76-136; also Beloff, op. cit.; George Rudé, The Crowd in History, A Study of Popular Disturbances in France and England 1730-1848 (London, 1964); and the recent study by Walter J. Shelton, English Hunger and Industrial Disorders. A Study of Social Conflict during the first decade of George III's reign (London, 1973). This paragraph and the two following are based on these sources. 
seemed comparatively untroubled by popular outbreaks, which seemed unlikely to threaten the existing social order. In the 1760's and after, however, when prices rose and bad harvests occurred more often, matters seemed very different. Rising social tensions and new social alignments, partly reflecting contemporary economic changes, were the cause of considerable concern to the government, which used the army, rather than the militia, to preserve public order. In this period the lower orders became involved in a defensive campaign to maintain the higher living standards which so many of them had enjoyed during much of the first half of the century; and their disposition to riot was certainly effective in persuading the rich to implement the machinery of parish relief and public charity.

It should be noted that the government's attitudes to these outbreaks did not necessarily accord with the responses of economic and poor-law writers, many of whom were certainly more hostile to the poor in the earlier period than after the mid-century. And in terms of poor-law policy the shift of opinion and intention from the Workhouse Test Act of 1723 to Gilbert's act of 1782 was considerable. ${ }^{1}$ The latter measure, by reserving the workhouses in newly-formed parish unions for those unable to work, reversed the earlier act, which had been designed to check applications for relief from able-bodied paupers by making entry into the house a condition of relief. It not only involved a shift from indoor to outdoor relief; it also emphasized the parish's responsibility to provide work for the unemployed, thereby preparing the way for more generous, if lax, principles and practices subsequently embodied in the Speenhamland system. And it is characteristic of Gilbert's more sympathetic attitude to the paupers which reflected the trends of opinion in the preceding quarter century - that charitable contributions were to be enlisted to provide rewards for good behaviour. ${ }^{2}$ Thus the line between public and private philanthropy was effectively blurred.

\section{IV}

Public and private provision for the relief of poverty in seventeenthand eighteenth-century England was patently inadequate. Nevertheless there is abundant evidence of both a sense of responsibility for the less fortunate members of society and good works designed to

1 For further discussion of this point see my article "Economic Thought and Poor Law Policy", loc. cit.

${ }^{2}$ Thomas Gilbert, A Bill, Intended to be offered to Parliament, for the better Relief and Employment of the Poor, within that Part of Great Britain called England (1775), p. 62. 
alleviate hardship. These activities defy enumeration or neat classification. They included individual and collective efforts to inaugurate and operate institutions designed for medical, educational and social welfare; proclamations from the Lords Justices instructing parish officials to relieve distress at the time of the great recoinage; royal orders requiring the Bishop of London to organise house-to-house collections for the poor; emergency aid for the victims of natural disasters, such as fires and floods; purchases of grain and other foodstuffs in times of dearth for resale to the poor at "normal" or customary prices below prevailing market levels; and repeated occasions when the poor were permitted or even encouraged to raid warehouses and impose their own taxation populaire on hated middlemen.

Historians of philanthropy have fully acknowledged the impossibility of drawing a clear-cut distinction between public and private assistance. Poor-law officials often had charge of private endowments or alms houses; the well-to-do sometimes pressed them to be more generous in hard times; and charity schools were influenced as much by the desire to produce a docile, industrious labour force as to educate their pupils. ${ }^{1}$ As Professor David Owen has noted, "Properly administered charities can almost be thought of as instruments of mercantilist policy in so far as they tended to safeguard national power", ${ }^{2}$ and whenever the divinely approved, "most lasting, valuable, and exquisite pleasure" 3 of giving became careless and indiscriminate, many voices urged restraint and emphasized the need to consider the harmful consequences of such outlays for the recipients, and for

1 For example, the Bishop of Norwich: "There must be drudges of labour (hewers of wood and drawers of water the Scriptures call them) as well as Counsellors to direct and Rulers to preside. [...] To which of these classes we belong, especially the more inferior ones, our birth determines. $\Gamma \ldots$ ] These poor children are born to be daily labourers, for the most part to earn their bread by the sweat of their brows. It is evident then that if such children are, by charity, brought up in a manner that is only proper to qualify them for a rank to which they ought not to aspire, such children would be injurious to the Community." Sermon Preached by the Bishop of Norwich at the Anniversary Meeting of the Charity Schools in and about London and Westminster, May 1, 1755. Quoted by M. G. Jones, The Charity School Movement, A Study of Eighteenth Century Puritanism in Action (Cambridge, 1938), p. 75.

2 David Owen, English Philanthropy 1660-1960 (London, 1965), p. 14. For example: "British benevolence, being thus united with native British fire, will diffuse the genuine spirit of patriotism through these realms, and we may hope to see such improvements in maritime affairs, as posterity looking back, will view with equal gratitude and applause." Jonas Hanway, Account of the Marine Society, 6th ed. (London, 1759), p. 13. Italics in original.

3 Owen, op. cit., p. 14. 
society at large. It was often claimed that charity was superior to public relief, because it was prompted by a higher motive; ${ }^{1}$ but while some maintained that the two were complementary, others regarded them as competitive. ${ }^{2}$

As already indicated, any overall assessment of poor relief in our period must take account of private philanthropy as well as the poor law. ${ }^{3}$ Here, as elsewhere, generalisations are suspect; yet it seems likely that historians have tended to underestimate their combined impact. One method has been to calculate a per capita figure, either in annual or weekly terms, based on estimates of total expenditures and population at a given date. ${ }^{4}$ Such a calculation is, of course, acknowledged to be rough and ready; but its effect is, inevitably, to make the resulting figure seem insignificant.

This procedure has two obvious shortcomings. One is that much voluntary charity was unrecorded, especially that associated with the cohesive and often paternalistic face-to-face relationships prevailing in rural communities. The second, more significant, point is that poor-relief outlays were obviously not distributed evenly over the whole population, either in space or in time, and should therefore be seen in most cases as marginal additions to income in an otherwise precarious or desperate situation..$^{5}$ In a matter of this kind timeliness

1 Yet not all motives were equally worthy. For example, Richard Nelson, in An Address to Persons of Quality and Estate, Ways and Methods of Doing Good (London, 1715), p. 254, argued that charity might be immediately profitable, for "an unexpected inheritance, the determination of a lawsuit in our favour, the success of a great adventure, an advantageous match, are sometimes the recompenses of charity in this world".

${ }^{2}$ For example, Henry Fielding in his Proposal for Making an Effectual Provision for the Poor (1753) considered that the poor unable to work could be largely or wholly supported by private charity. Other commentators maintained that the high level of poor rates discouraged private charity.

3 It is generally accepted that most poor-law outlays consisted of casual doles or payments in kind. This was doubtless the easiest method by which untrained, sometimes unpaid and often overworked parochial officials could discharge their obligations. But this does not preclude the possibility that this was the most appropriate and efficacious procedure.

1 For example, Wilson, op. cit., p. 235; Clarkson, op. cit., p. 171-72, 231.

5 For example: "What, too, is the condition of the great body of the poor, employed in the several branches of this manufacture [i.e. wool]? [...] Deplorable beyond expression. Some quite destitute of employment, and others halfemployed, and almost all obliged to fly (where else can they fly) to the landed interest for at least partial support. [...] It is a fact (I speak it from knowledge) that many parishes, at this instant, pay the carriage of wool, to and from the spinning houses, at the distance of twenty, thirty, and even forty miles, for the sake of finding some employment for their poor." Anon., An Answer to Sir John Dalrymple's Pamphlet upon the Exportation of Wool (1782), pp. 29-30. No doubt this was a partisan statement. But the situation it described was by 
is crucial. The failure to eradicate, or to effect a significant reduction in the level of, poverty cannot be surprising to those familiar with its persistence in affluent industrial societies. Yet charitable and poor-law payments constituted a sizeable tranfer of incomes to persons with a high propensity to consume from those with a comparatively high propensity to save. ${ }^{1}$ The impact on effective demand may have been slight, but it should not be entirely overlooked.

Far more important, however, was the effect of relief in preserving life, keeping up the labourer's morale and sense of security, and maintaining the higher levels of nutrition, energy and productivity on which many eighteenth century observers commented. Recent historians have recognized the first of these consequences, while possibly underestimating its importance at a time when rising population was probably contributing directly to economic growth. ${ }^{2}$ But the broader social value of the poor law seems to have been lost sight of, maybe because it cannot be quantified. It may be worth recalling the views of earlier historians who considered that it encouraged social peace (a positive value transcending the interest of the governing class), helped to unite social classes, reduced the brutality of the labourer's struggle for survival, and had indirect benefits even for those workers who never received public relief. ${ }^{3}$ Its effects on the

no means unique. For acknowledgement of the precarious situation in growing branches of manufacturing see, for example, Wilson, op. cit., p. 344, and Ashton, Economic Fluctuations, op. cit., pp. 145, 177.

1 Clarkson, op. cit., p. 171. According to a much earlier pre-Keynesian writer, the poor rate was largely a wages fund, which may have helped to keep the poor from starving but probably depressed the "industrious and competent" who were immediately above that level. B. Kirkman Gray, A History of English Philanthropy, From the Dissolution of the Monasteries to the Taking of the First Census (London, 1967; originally published in 1905), pp. 220-21. This argument recalls the early-nineteenth-century case against the Speenhamland system. It assumes a fixed wages fund or, more precisely, that sums spent on poor relief would otherwise have been spent in some other manner, so that the net employment-generating effects of poor relief would be zero or negligible. Such a contention is, of course, highly suspect.

2 The counterfactual assumption that but for private and public aid some of the poor would have starved is often implied or explicitly stated; e.g., Gray, op. cit., p. 221; Wilson, op. cit., p. 235: "Often, the poor could only look for their immediate salvation to the voluntary redistribution of income through charity and poor relief"; Clarkson, op. cit., pp. 237-38: for the poor, poverty "meant receiving incomes too small to support existence without public or private charity".

${ }^{3}$ E. M. Leonard, The Early History of English Poor Relief (Cambridge, 1900), pp. 302-04. Cf. S. and B. Webb, op. cit., pp. 402, 404-05; Marshall, op. cit., pp. 1, 250, 252-54. Recognition of the social value and, more particularly, the elevated aims of the poor-law system is not, of course, incompatible with severe criticism of its actual workings. 
workers' psychology are even more difficult to assess, but it is at least conceivable that the situation was one whereby in growth industries in normal times labour incentives were higher than if average wages had been significantly higher or lower, and no relief had been forthcoming. When Mandeville remarked in his Fable of the Bees (1714) that "the poor have nothing to stir them to labour but their wants, which it would be wisdom to relieve but folly to cure", he may have been stating an elementary truth. Jonas Hanway, a realistic philanthropist who described the poor rates as "a stream of pure water for the support of life", added:

"I question much if we should be near so rich as we are, if the common people did not live so much from hand to mouth. This is a good, though it arises seemingly from an evil; our fellow subjects enjoy an active disposition, yet generally work only in proportion to their necessities."1

By the third quarter of the eighteenth century it may have become increasingly clear to perceptive observers that despite the "squalor, with spells of privation which were endured as the common lot", there were positive natural advantages in a situation where the workers could "for the most part enjoy, when they were at work, a coarse abundance of food and drink - an abundance reflected in the published dietaries both of workhouses and large private establishments - and, above all, a jovial freedom to live irregularly, and to come and go as they please". ${ }^{2}$ It is, of course, impossible to assess the economic and social value of freedom, which existed despite the seemingly oppressive Settlement Laws. But present-day scholars are more likely to consider the effects of the workers' "rude exuberance" on their energy and fertility. ${ }^{3}$ In so far as they prevented living

1 Jonas Hanway, Letters to the Guardians of the Infant Poor and to the Overseers of the Parish Poor (1767), p. 13.

$2 \mathrm{~S}$. and B. Webb, op. cit., p. 419 . For a more qualified assessment of diets in workhouses, orphanages and schools see J. C. Drummond and Anne Wilbraham, The Englishman's Food. A History of Five Centuries of English Diet, revised by Dorothy Hollingsworth (London, 1957), pp. 223-228.

${ }^{3}$ On the question of energy see the fascinating unpublished paper by Herman Freudenberger and Gaylord Cummins, "Health, Work and Leisure in the Industrial Revolution" (Tulane University, March 1973). Their argument suggests that rising food consumption and improved nutrition in the first half of the eighteenth century may have significantly improved the biological quality of the English labour force and increased its energy and productivity. This supports the contention that there may have been a positive relationship between poor-law expenditure and fertility. Cf. H. J. Habakkuk, Population growth and Economic Development Since 1750 (Leicester, 1971), p. 39. A 
standards from falling in times of distress, contemporary philanthropists may have succeeded in maintaining life, sustaining the morale and energy of the work force, and, after a long period of relatively low food prices, preserving those rising expectations on which the incentive to increased productivity so often depended. We should, after all, bear in mind that poverty is largely, if not mainly, a subjective condition. $^{1}$

As indicated at the outset, the main argument of this paper is somewhat speculative. There is no reliable evidenec of trends in contemporary opinion, the volume of private or public charity, or of the precise nature and effects of the poor law. Our knowledge of the labourer's living standards is depressingly meagre, not to mention his morale and productivity. But there is no doubt that poverty was the principal social problem of the period and that there is considerable scope for future research. We need to know more of contemporary attitudes and their relationship to poverty; we need detailed local studies of public and private relief payments; and more careful attempts to examine labour conditions, especially in relation to nutrition, hours of work, the number of days worked per annum, and other influences on productivity. Whether this will lead to a revision of current conceptions of the role of labour in the economy is a matter for the future.

somewhat similar argument appears in Mark Blaug, "The Myth of the Old Poor Law and the Making of the New", in: Journal of Economic History, XXIII (1963), pp. 151-84.

'See, for example, Peter Townsend, "The Meaning of Poverty", in: British Journal of Sociology, XIII (1962), pp. 210-27; also Peter Townsend, The Culture of Poverty (n.p., n.d.), p. 46. 